\section{Difference on the Polarogram of the Metabolic Materials from Pathogenic and Non-patho- genic Dysentery Bacillus.}

\section{Koichi Matsushima}

Shizuoka Public Health Department.

\section{I.まえがき}

1898年志賀の Shigellae shigae 発見以来細菌 学, 疫学, 或いは毒素, 抗毒素検索について多 くの学者の優れた業績が多数報告されて居る. 然し，その後に続々発見された Sh. flexneri, sonnei 菌等の毒素は勿諭血清学的型（serotype）の生化学的検索 ${ }^{1)}$, 及び患者与り检出の病 原性菌代謝物質即方毒素己保菌者占り検出の非 病原性菌代謝物質の相違に就ての研究業績は少 ないと考光られる。「Sh. flexneri の毒素は少な くとも多糖類の毒性と特異性を有しており， $\mathrm{O}$ antigen の毒性と抗原性をおえらくもつている 絓合琶白質にはトリプシン耐性のものがあ る.」尘と云われているが，てれとても非病原性 菌の代謝物質との比較研究保見当引ない。笔者 は真正赤痢患者及び保菌者上り検出のSh. flexneri 1b，2a，3a，4a の培養滤液与り蛋白質, 及 び〔脱ステアリン酸燐脂質十多糖類〕の分画絬 晶を生成せしめ，乙れにつきポーラログラフで 将波電位老求め，病原性，非病原性並びに血清 学的型の成分の相違に就て知見を得たので記す ととにする。

\section{II．実験方法ならびに材料}

\section{1) 笑験方法}

具正赤痢患者及び保菌者より検出の菌培養滤 液及び硫安分画 ${ }^{3}$ に上り析出せしめた結晶の組 成をペーパークロマトグラブタ や光電比色計で 検索し，結晶の毒性を動物で実験し，乙れら真 正患者菌の病原性毒素並に保菌者菌の非病原性 代謝物質の半波電位をポーラログラフで求め相 違を認めるととを実験目的とした。
病原性, 非病原性赤癒菌代謝物質

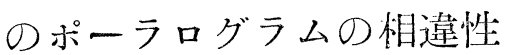

松島耕一

静岡竹衛生部

2. 害験材料

Sh. flexneri 菌はいずれも普通ブイヨン液体 培地即方

肉汁 (牛肉 500 瓦存水 1 立で

煮沸渗出滤過した液）………...... 1 立

ペプトン……......................1

食塩……………………... 5 瓦

寒天 (精製) …………………1.5

$$
\mathrm{pH}=7.0 \sim 7.2
$$

に 10 日間 $37^{\circ} \mathrm{C}$ で培養する。菌体内毒素でも 菌体外毒素でもオールド・カルチャーを行光ば 毒素は培養濾液中に析出する。培養滤液に約 $1 / 2$ 容の $99.5 \%$ エ夕ノ一ルを添加し, $80 \sim 100^{\circ} \mathrm{C}$ に加熱し，55\%に飽和硫安を添加せしめる. 更 に加熱すれば溶液は向流分配に上り黄色の下層 と橙色の上層に分離する。上下耐層を分取し， 濾過する、下層を加熱し，エ夕ノ一ル分を放冷す る。真正患者菌の培養濾液汃らは (a) 㼛平六角 形結晶，(b) 柱状六面体，(c) 柱状四面体, (d) 柱 状円錐型及び (e) 唡平四角形結晶の析出がみら れる。保菌者菌の培養滤液では各結晶が析出し ても，扁平六角形結晶は真正思者菌の場合の数 十分の一の量に過ざない，上層を加熱し，エ夕 人一ル分を放泠するに，保菌者の菌培養濾液か らは殆んど析出物質が認められないが，真正惠 者の菌培養濾液では放冷前にも極めて粘性があ り，放冷に上つて (f) 正方形六面体の結晶が析 出する、結晶 (a) は醳素レシチナーゼAがレシ チンを分解して生成するモノ・アチール・グリ セリール・ホスファタイディルコリンに鉄, 二 ッケル，エヌ・アセテール・ディー・グルコサ ミン及び 2 -アミノーグルコース（4a の場合は 
マンノ・サッカリク陵）より成る絬沾である扑 がペーパークロマトグラフで㽎时できる。

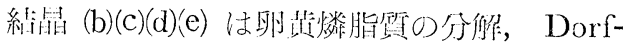
man 及び Ott のヒアルロニダーゼの深性浚测

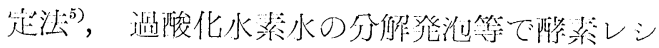
チナーゼ $\mathrm{A}$ ，ヒアルロニダーゼ，及びパーオキ

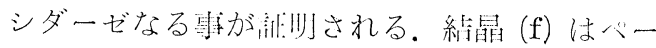
パークロマトグラフで 2・4-ダィ・ニトロフェ

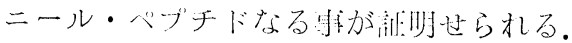

\section{III，動 物 実 験}

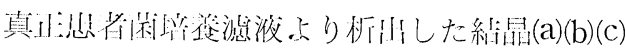

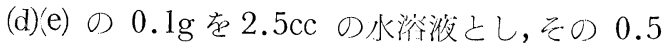
cc（結晶として $20 \mathrm{mg}$ ) 夗を 約 $16 \mathrm{~g}$ のハツカ ネズミに金属ゾンデーで䋂回投方するに㞹時に

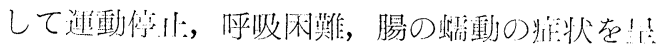

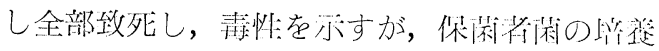

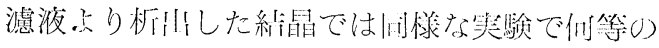
症状をも是しない。絬间（f）の水溶渡をモルモ

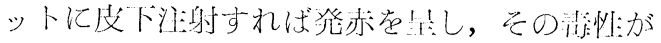
証明される。

\section{IV. ポーラログラフ実験}

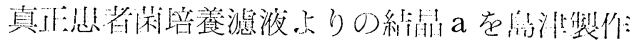
所製 RP-I 㕵自記方式のポーラログラフを似州

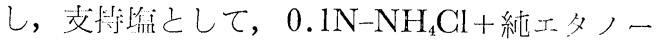
ル (1:4) を，極大抑制剂として，0.01\%ゼラ

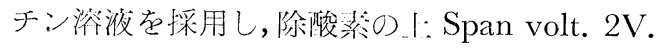
(vs. S.G.E.), Initial volt. Ov, Full scale $20 \mu \mathrm{A}$, Damping 3 でポーラロダラム苯とれいぜけ波

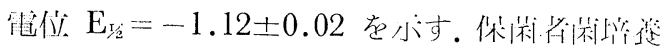
㶐没よりの䌅晶aでは间条作で，ボーラログラ ムをと万に，半波電位 $\mathrm{E}_{1 / 2}=-1.28 \pm 0.02$ 造小 す.

モノーアチール・グリ七りール・ホスツッタ

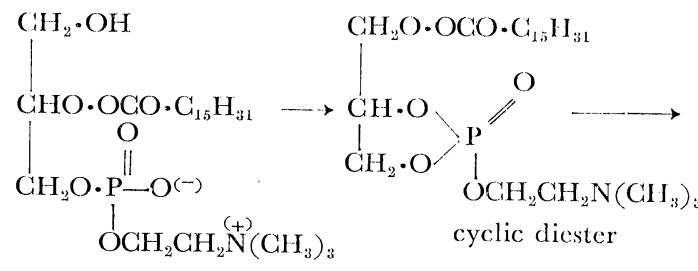

$\boldsymbol{\alpha}$-monoacylglycerylphosphatidylcholin

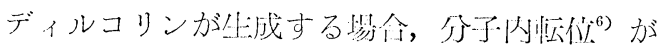
起り得る。

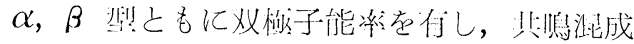

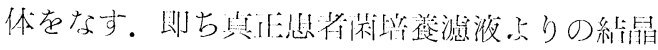

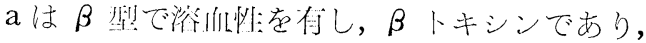

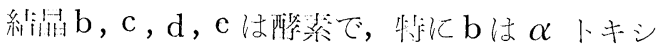
ンである.

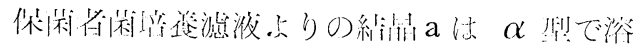

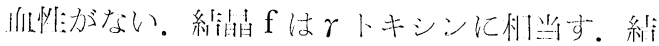
品a (1) $0.1 \mathrm{M}-\mathrm{Na}_{3} \mathrm{PO}_{4}(\mathrm{PH}=10.0),(2) 0.1 \mathrm{~N}$ $-\mathrm{LiCl}(\mathrm{pH}=2.6)$ を支将焦として, Span volt. 2V. (vs. S.C.E.), Initial volt. 0, Full scale $10 \mu \mathrm{A}$, Damping 3 でポーラログラム在とれば 准波隹。

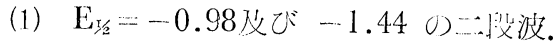

(2) $\mathrm{E}_{1 / 2}=-0.96$ 存胻，(1) は Dーマンノイタ 悛则占 $\left[\mathrm{HO}_{2} \mathrm{C}(\mathrm{CHOH})_{4} \mathrm{CH}_{2} \mathrm{OH}(-+++)\right]$ でセロタイブ-4a の将令にホし，(2) は D-グ ルコリミン㺫ち $〔 \mathrm{CHO} \cdot \mathrm{CHNH}_{2}(\mathrm{CHOH})_{3}$. $\mathrm{CH}_{2} \mathrm{OH}(+-++)$ 〕で也山タブー1 b, 2 a, 3 a の蓝似小される。

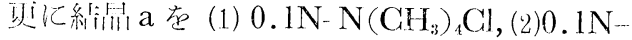

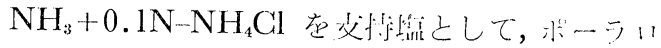

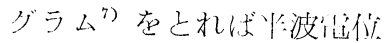

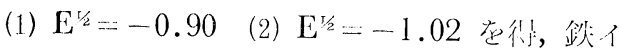
オン $\left(\mathrm{Fe}^{3+}\right)$ 丈びニッケルイオン $\left(\mathrm{Ni}^{3+}\right)$ 在小

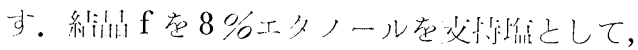

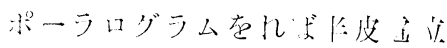

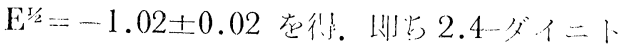

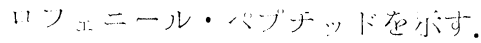

\section{V.あとがき}

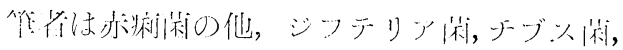

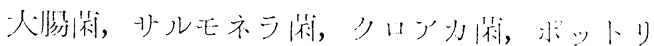

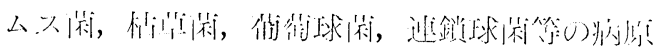

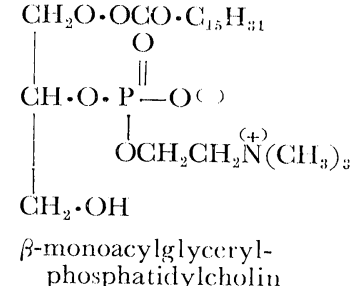

$\mathrm{CH}_{2} \mathrm{O} \cdot \mathrm{OCO} \cdot \mathrm{C}_{1 ;} \mathrm{H}_{3: 1}$ phosphatidylcholin 
性毒素及び食中毒の検索, 中毒患者の血液, 胃 液の生化学的研究にポーラログラフをペーパー クロマトグラフ, 光電比色計, 光電光度計, 電位 差滴定法等と併用し, 病原性代謝物質は非病原 性のものとはその電位に相違があり, 食中毒の 中毒期間の血液でも正常時, 快復後の血液とは その血清中に毒素の場合と同様に化学分子式は 同一なるに，電位の異なつた共鳴混成体物質が 存在する事を知り得た。更に赤痢菌では各菌の 血清学的に特異性を附与する多糖類に相違があ り，セロタイプの分類の差異がうかがわれる. 細菌学でモルホロギイ, 七ロロギイ及び糖の分 解でけでは解決難解で, 生化学の分野が, 之ク ロバイオロジイとして取入れられている現今, 他の機器と共にポーラログラフの導入は他に見 られない特徵のある事が感ぜられる。

\section{文献}

1) William Burrows, Ph.D. Textbook of Microbiology, 16, 495, 1959.

2) Martin Burger, Bacterial Polysaccharide, 1, 159, 1950.

3) Ernest F. Gale, The Chemical Activities of Bacteria, 3, 65, 1952.

4) Edgar Lederer \& Michael Lederer, Chromatography, 1957.

5) 赤堀, 水島 : 醭素研究法 II.

6) Verkade (1940), Fulton(1943), Dolman(1943), Surgalle \& Hite (1945)., The Journal of the Bacteriology, etc.

7) I.M. Kolthoff and James J. Lingane, Polarography. Vol. 1 2.

(1960 年 4 月 20 日受理) 


\section{Summary}

From 1898, Shigellae shigae was discovered by Shiga, there are many excellent data, which are best reference on the bacteriology, epideminology, toxicology. But we know a few data that are on the reference of biochemistry, serology, and difference of the metabolic materials from pathogenic and non-pathogenic dysentery bacillus. I have studied on these points by polarography, and the results are as follows:

1. The methods of exercise and thier materials.

1) By countercurrent of ethanol and water with saturated ammonium sulfate, produced crystals from the liquid medium of old cultured bacillus, detected from patients and germ-carriers. Paperchromatographed, measured by use of spectrophotometer and tested by use of experımental animals. Thus, we can observe the difference between the metabolic materials from pathogenic and those from non-pathogenic dysentery bacillus by the half wave potential of their polarogram.

2) Sh. flexneri bacillus was cultured in the suitable liquid medium for 10 days at $37^{\circ} \mathrm{C}$. Then, the filtrate of the cultured medium is added $1 / 2$ vol. of $99.5 \%$ ethanol, heated at $80^{\circ} \mathrm{C}$ and added ammonium sulfate at $55 \%$ and saturated. After further heating, extracted liquid is separated into two phase, upper being yellow and lower being orange. Flat six-angle crystals, six-surface columnar, four-surface columnar, conic columnar and octahedron crystals are produced from the lower phase.

3) Polarogram.

$\mathrm{E}_{1 / 2}$ of flat six-surface columnar from cultured medium of pathogenic bacillus in the supporting electrolyte of $0.1 \mathrm{~N}-\mathrm{NH}_{4} \mathrm{Gl}+$ ethanol abs. $(1: 4)$ is $-1.12 \pm 0.02 \mathrm{v}$. and $\mathrm{E}_{5 / 2}$ of flat six-surface columnar from cultured medium of non-pathogenic bacillus is -1.28 \pm 0.02 .v.

The former is $\beta$-monoacylglycerglphosphatildycholin and the latter is $\alpha$-monoacylglycerylphosphatidylcholin.

Using $0.1 \mathrm{M}-\mathrm{Na}_{3} \mathrm{PO}_{4}(\mathrm{pH}=10.0)$ and $0.1 \mathrm{~N}-\mathrm{LiCl}(\mathrm{pH}=2.6)$ as electrolyte, $\mathrm{E}_{5 / 2}$ of the flat six-surface columnar from pathogenic bacillus $4 \mathrm{a}$ is $-0.98 \mathrm{v}$. and $-1.44 \mathrm{v}$., and $\mathrm{E}_{1 / 2}$ of the $\mathrm{lb}$ is $-0.96 \mathrm{v}$. The former is D-mannoic acid and the latter is D-glucosamine.

Using $0.1 \mathrm{~N}-\mathrm{N}\left(\mathrm{CH}_{3}\right)_{4} \mathrm{Cl}$ and $0.1 \mathrm{~N}-\mathrm{NH}_{3}+0.1 \mathrm{~N}-\mathrm{NH}_{4} \mathrm{Cl}$ as electrolyte, $\mathrm{E}_{1 / 2}$ of the flat six-surface columnar from pathogenic bacillus is $-0.90 \mathrm{v}$. and $-1.02 \mathrm{v}$. The former is $\mathrm{Fe}^{3+}$ and the latter is $\mathrm{Ni}^{2+}$.

Using $8 \%$ ethanol as electrolyte, $\mathrm{E}_{1 / 2}$ of the octahedron crystals from cultured medium of pathogenictive bacillus is $-1.02 \pm 0.02 \mathrm{v}$. This is 2.4-dinitrophenyl-peptide. Thus we can identify the metabolic materials of pathogenic from those of non-pathogenic dysentery bacillus by the polarographie method. This method may be able to use for test on other toxins of bacteria and toxins from food poisoning. 